\title{
Interleukin-1 $\alpha$ stimulates steroidogenic acute regulatory protein expression via p38 MAP kinase in immature rat Leydig cells
}

\author{
K Svechnikov ${ }^{1,3}$, D M Stocco ${ }^{2}$ and O Söder ${ }^{1}$ \\ ${ }^{1}$ Department of Woman and Child Health, Pediatric Endocrinology Unit, Karolinska Institute and Hospital, S-17176 Stockholm, Sweden \\ ${ }^{2}$ Department of Cell Biology and Biochemistry, Texas Tech University Health Sciences Center, Lubbock, Texas 79430, USA \\ ${ }^{3}$ Endocrinological Genetics Unit, Institute of Cytology and Genetics, 630090 Novosibirsk, Russia \\ (Requests for offprints should be addressed to K Svechnikov, Department of Woman and Child Health, Astrid Lindgren Children's Hospital, Pediatric \\ Endocrinology Unit, Karolinska Institute and Hospital (Q2:08), SE-171 76 Stockholm, Sweden; Email: konstantin.svechnikov@kbh.ki.se)
}

\begin{abstract}
We have investigated the involvement of the steroidogenic acute regulatory (StAR) protein in interleukin-1 $\alpha$ (IL-1 $\alpha)$-induced steroidogenesis in immature (40-day-old) and adult Leydig cells in vitro. Further, IL-1 $\alpha$-mediated signaling pathway(s) controlling StAR expression in immature Leydig cells were also studied. IL-1 $\alpha$ stimulated both androgen production and StAR protein expression in a dose- and time-dependent manner in immature but not adult Leydig cells. These effects of IL-1 $\alpha$ were prevented by pretreatment of the cells with the specific inhibitors of the p38 MAP kinase, SB203580 and PD169316, suggesting that this kinase is an important part of IL-1 $\alpha$ signaling in the immature Leydig cell. The present results suggest that $\mathrm{IL}-1 \alpha$, which is constitutively produced by the rat testis from postnatal day 25 , is an important paracrine regulator of postnatal Leydig cell maturation. Regulation of StAR protein expression is one of the possible mechanisms by which IL-1 $\alpha$ contributes to the differentiation of immature Leydig cells into adult cells.
\end{abstract}

Journal of Molecular Endocrinology (2003) 30, 59-67

\section{Introduction}

Interleukin- $1 \alpha(\mathrm{IL}-1 \alpha)$ is a multifunctional cytokine induced in association with inflammation, infection and cancer (Dinarello 1991), and has also been found to be constitutively produced by normal tissues (Tovey et al. 1988) including the testis (Khan et al. 1987, Jonsson et al. 1999, Sultana et al. 2000). In the rat testis, IL- $1 \alpha$ mRNA and protein are highly expressed from postnatal day 25 and evidence indicates that IL- $1 \alpha$ is involved in the paracrine regulation of spermatogenesis (Pöllänen et al. 1989, Parvinen et al. 1991, Wahab-Wahlgren et al. 2000, Gustafsson et al. 2002) as well as Leydig cell steroidogenesis (Calkins et al. 1988, Moore \& Moger 1991, Svechnikov et al. 2001). IL-1 $\alpha$ has been shown to inhibit luteinizing hormone (LH)/human chorionic gonadotrophin (hCG)- and cAMP-stimulated testosterone production by Leydig cells (Verhoeven et al. 1988, Moore \&
Moger 1991, Svechnikov et al. 2001), with the major site of inhibition occurring at the level of the 17a-hydroxylase/C17-20 lyase enzyme (Verhoeven et al. 1988, Svechnikov et al. 2001). Reports on IL- $1 \alpha$ action on basal testosterone production are conflicting, demonstrating either stimulatory (Verhoeven et al. 1988, Moore \& Moger 1991, Svechnikov et al. 2001) or no effects (Calkins et al. 1988). Recently, we have found that the effect of IL-1 on steroidogenesis was dependent on the stage of maturation of the responding Leydig cells (Svechnikov et al. 2001). IL-1 isoforms were shown to stimulate basal testosterone production by immature but not adult Leydig cells and the effect was found to be IL-1 type I receptor (IL-1RI)-mediated. We hypothesized that the acute stimulatory effect of IL- $1 \alpha$ on steroidogenesis by immature (40-day-old) Leydig cells might be mediated by the stimulation of steroidogenic acute regulatory (StAR) protein expression, whose 
function is to translocate cholesterol from the outer to the inner mitochondrial membrane, the rate-limiting step in steroid hormone formation (Stocco 2001). Our attention was focused on IL- $1 \alpha$-mediated signaling pathway(s) controlling StAR expression in immature Leydig cells. It is generally accepted that StAR gene expression is positively regulated by cAMP-dependent protein kinase A in steroidogenic cells (Christenson \& Straus 2000), although other signaling systems have also been implicated in StAR gene expression (Wang et al. 2000, Gyles et al. 2001). The mitogen-activated protein (MAP) kinase family, which includes extracellular signal-regulated kinases (ERK2/1), c-Jun N-terminal kinases, and p38 kinases (p38 MAP kinase) could also be involved in the regulation of StAR gene expression. These enzymes are the terminal kinases in three distinct but interacting signal transduction cascades (Pearson et al. 2001) and are activated by IL-1 in different cell systems (Bankers-Fulbright et al. 1996). ERK2/1 was recently shown to regulate StAR gene expression by stimulating steroidogenic factor 1 phosphorylation in mouse adrenocortical cells (Gyles et al. 2001). To the best of our knowledge, virtually nothing is known about the role of p38 MAP kinase in steroidogenic cells. The purpose of the present study was to investigate whether StAR protein is involved in IL- $1 \alpha$-induced stimulation of steroidogenesis in immature Leydig cells in culture. In addition, the IL- $1 \alpha$-mediated signaling pathway(s) controlling StAR expression were also investigated. We found that IL- $1 \alpha$ is a potent stimulator of StAR protein expression in immature but not adult Leydig cells. IL- $1 \alpha$-induced StAR expression is positively regulated by p38 MAP kinase in immature Leydig cells.

\section{Materials and methods}

\section{Materials}

Dulbecco's modified Eagle's medium (DMEM)Ham's nutrient mixture F12, modified Eagle's medium, Hank's balanced salts solution (HBSS) without $\mathrm{Ca}^{2+}$ and $\mathrm{Mg}^{2+}$ and penicillinstreptomycin were obtained from Gibco/BRL (Life Technologies, Paisley, Strathclyde, UK). BSA (fraction V), Percoll, Hepes, collagenase type I, 22(R)-hydroxycholesterol (22R-OHG) and p38 MAP kinase antibodies (rabbit polyclonal IgG, affinity purified) were obtained from Sigma Chemical Co. (St Louis, MO, USA). Cytochrome P450 side chain cleavage enzyme (P450 scc) antibodies (rabbit polyclonal IgG, affinity purified) were obtained from Chemicon International Inc. (Temecula, CA, USA). Rat recombinant IL-1 $\alpha$ was purchased from RD Systems (Oxon, UK). PD169316 and SB203580 were obtained from Calbiochem (La Jolla, CA, USA). Phospho-specific p38 MAP kinase antibodies (rabbit polyclonal IgG, affinity purified) were purchased from New England Biolabs, Inc. (Beverly, MA, USA). The IL-1RI antibodies, mouse and rat reactive (rabbit polyclonal IgG, affinity purified) were obtained from Santa Cruz Biotech Inc. (Santa Cruz, CA, USA).

\section{Animals}

Male Sprague-Dawley rats (B\&K Laboratories, Sollentuna, Sweden) aged 40 and 65-75 days were used as a source of immature and adult Leydig cells respectively (Ge et al. 1996, Mendis-Handagama \& Ariyaratne 2001). Animals were fed a freely available standard pellet diet and water. Animal experiments were approved by the Northern Stockholm Animal Ethics Committee (registration no. N102/99).

\section{Isolation and culture of Leydig cells}

Leydig cells were prepared from immature (40-day-old) and adult rat testes by collagenase treatment as described earlier (Svechnikov et al. 2001). Briefly, decapsulated testes were incubated with collagenase $(0.25 \mathrm{mg} / \mathrm{ml})$ for $20 \mathrm{~min}$ at $37^{\circ} \mathrm{C}$. Crude interstitial cells were collected by centrifugation at $300 \boldsymbol{g}$ for $10 \mathrm{~min}$ and then washed twice in $0 \cdot 1 \%(\mathrm{w} / \mathrm{v})$ BSA in HBSS. To obtain purified Leydig cells, the crude cell suspension was loaded on top of a discontinuous Percoll gradient (20, 40, 60 and 90\% Percoll in HBSS) and centrifuged at $800 \boldsymbol{g}$ for $20 \mathrm{~min}$. The fractions enriched in Leydig cells were then centrifuged through a continuous self-generated $60 \%$ Percoll gradient at $20000 \boldsymbol{g}$ for $30 \mathrm{~min}$ at $4{ }^{\circ} \mathrm{C}$. The purity of Leydig cells was $90 \%$, as determined by histochemical $3 \beta$ hydroxysteroid dehydrogenase staining (Payne et al. 1980). Cell viability was greater than $90 \%$ as assessed by trypan blue exclusion. Purified Leydig cells were washed twice with DMEM-F12 and 
resuspended in DMEM-F12 supplemented with $15 \mathrm{mM}$ Hepes (pH 7•4), $1 \mathrm{mg} / \mathrm{ml} \mathrm{BSA}, 365 \mathrm{mg} / \mathrm{l}$ glutamine, $100 \mathrm{IU} / \mathrm{ml}$ penicillin and $100 \mu \mathrm{g} / \mathrm{ml}$ streptomycin. The cells $\left(1.5 \times 10^{5}\right.$ cells $\left./ \mathrm{ml}\right)$ were plated in a volume of $100 \mu \mathrm{l}$ in 96-well plates (Falcon, Franklin Lakes, NS, USA) and cultured for $24 \mathrm{~h}$. The culture medium was replaced by fresh medium and the cells were pre-incubated with the specific inhibitors of the p38 MAP kinase, PD169316 and SB203580 $(0 \cdot 01-0 \cdot 1 \mu \mathrm{M})$ for $30 \mathrm{~min}$, followed by incubation with IL-1 $\alpha$ $(20 \mathrm{pg} / \mathrm{ml})$ or $22 \mathrm{R}-\mathrm{OHC}(1 \mu \mathrm{M})$ for another $24 \mathrm{~h}$. The range of concentrations of the inhibitors used was specific for inhibition of p38 MAP kinase without affecting activities of a number of other protein kinases (Davies et al. 2000). No changes in viability and the cell morphology after treatment with IL- $1 \alpha$ were found.

\section{Testosterone determination}

Culture media were collected and stored at $-20{ }^{\circ} \mathrm{C}$ until assayed for testosterone concentrations with a Coat-a-Count RIA kit (Diagnostic Products Corp., Los Angeles, CA, USA), according to the manufacturer's instructions.

\section{Western blot analysis}

The effects of IL- $1 \alpha$ and the inhibitors on p38 MAP kinase phosphorylation and StAR expression was analyzed by PAGE/Western blot. The cells were washed twice with PBS and then lysed and sonicated in a lysis buffer containing $62.5 \mathrm{mM}$ Tris-HCl (pH 6.8), 2\% SDS, 50 mM dithiothreitol and $10 \%$ glycerol. The cytosolic fraction was collected as a supernatant after centrifugation at $10000 \mathrm{~g}$ for $6 \mathrm{~min}$. Proteins from whole Leydig cells $(30 \mu \mathrm{g}$ from each sample) were resolved on $10 \%$ SDS/polyacrylamide gels and electrophoretically transferred to Hybond-P polyvinylidene difluoride membranes (Amersham Pharmacia Biotech, Amersham, Bucks, UK), using $25 \mathrm{mM}$ Tris, $185 \mathrm{mM}$ glycine, $\mathrm{pH} 8 \cdot 3$, containing $20 \%$ methanol. Following transfer, the membrane was incubated in a blocking buffer (Tris-buffered saline (TBS) buffer containing 5\% non-fat dry milk) for $1 \mathrm{~h}$ and washed three times with TBS/Tween $0 \cdot 1 \%(3 \times 10 \mathrm{~min})$. Membranes were incubated with antibodies directed to phospho-p38 MAP kinase and total p38 MAP kinases according to the manufacturer's specifications (Sigma and New England Biolabs). StAR polyclonal antiserum (Clark et al. 1994) and P450 scc antibodies were used for incubation at 1:4000 dilution in TBS containing $5 \%$ non-fat dry milk overnight at $4{ }^{\circ} \mathrm{C}$. The IL-1RI antibodies were used at 1:500 dilution at the same conditions as described for StAR protein. After washing, membranes were incubated with horseradish peroxidase-conjugated donkey anti-rabbit IgG secondary antibody (Amersham Pharmacia Biotech). Blots were incubated with ECL Plus Western blotting agent (Amersham Pharmacia Biotech) and exposed to X-ray film (Amersham Pharmacia Biotech).

\section{Statistical analyses}

The X-ray films were scanned using an HP ScanJet 5100C and HP PrecisionScan software (Hewlett Packard Sverige AB, Kista, Sweden). The images obtained were analyzed using NIH Image 1.57 software. Levels of StAR, P450 scc and IL-1RI were expressed as the fold difference (mean \pm S.E) vs cultured untreated control cells or adult cells in the case of IL-1RI. The densitometry value of the control was set to 1 . Statistical significance between groups was determined using Student's $t$-test. The results from dose-response experiments were analyzed by one-way ANOVA where appropriate and supplemented by the Dunnett $t$-test. $P<0.05$ was considered as significant.

\section{Results}

\section{IL-1RI is more highly expressed in immature than adult rat Leydig cells}

We examined the IL-1RI protein level in immature and adult rat Leydig cells. Whole cell protein extract was prepared and analyzed by Western blotting. Leydig cell IL-1RI migrated with an apparent molecular mass of $80 \mathrm{kDa}$, and was expressed more strongly $(2 \cdot 2$-fold, $P<0 \cdot 05)$ in immature than in adult cells (Fig. 1).

\section{Dose-dependent and time-dependent stimulation of StAR expression by IL-1 $\alpha$ in immature Leydig cells}

Our previous findings have shown that IL-1 isoforms significantly stimulate steroidogenesis by 


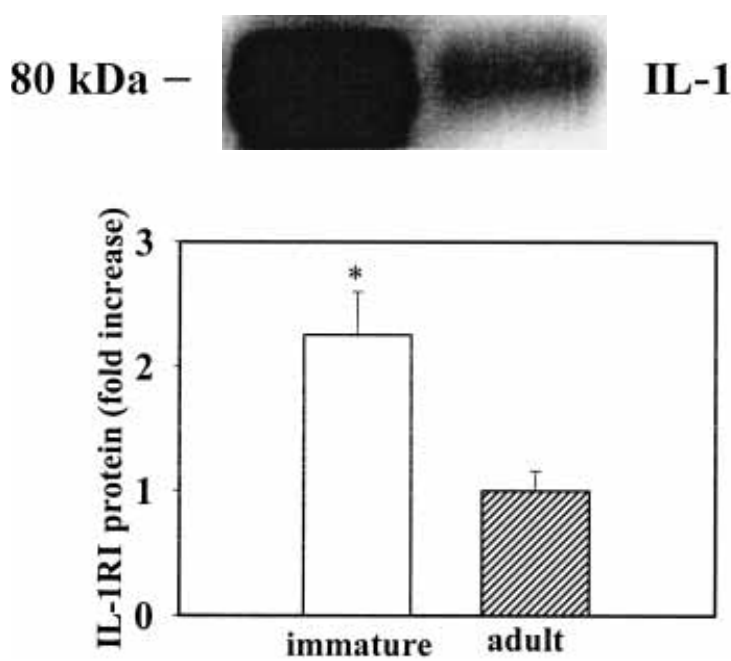

Figure 1 Immature Leydig cells express higher levels of IL-1RI protein than adult Leydig cells. Whole cell lysates were prepared from cultured Leydig cells and $50 \mu \mathrm{g}$ total protein were subjected to immunoblotting with anti-IL-1RI antibodies. Each IL-1RI-specific band was quantified using $\mathrm{NIH}$ Image software and expressed as the fold difference between immature and adult Leydig cells. The position of the molecular mass marker $(80 \mathrm{kDa})$ is indicated. Top, representative blot. Bottom, data from four separate Leydig cell preparations are presented (means \pm S.E.). ${ }^{*} P<0.05$ compared with adult cells.

immature but not adult Leydig cells (Svechnikov et al. 2001). As shown in Fig. 2, immature but not adult Leydig cells were capable of significant (7·6-fold over control, $P<0 \cdot 01)$ expression of StAR protein in response to IL-1 $\alpha$. The basal testosterone secretion was $1.02 \pm 0.30 \mathrm{ng} / \mathrm{ml}$ in immature cells and $3 \cdot 80 \pm 0 \cdot 26 \mathrm{ng} / \mathrm{ml}$ in adult Leydig cells. Further, IL-1 $\alpha$ was found to stimulate StAR expression in cultured immature Leydig cells in a dose-dependent manner. A significant effect (3-fold over control, $P<0 \cdot 05)$ on StAR expression was observed at IL-1 $\alpha$ concentrations as low as $5 \mathrm{pg} / \mathrm{ml}$, and maximal induction (9.5-fold over control, $P<0 \cdot 01)$ was found at IL- $1 \alpha$ concentrations of $20 \mathrm{pg} / \mathrm{ml}$ (Fig. 3A). Coincident with the increase in StAR protein levels, testosterone production by Leydig cells was increased (4-fold over control) at a concentration of $20 \mathrm{pg} / \mathrm{ml} \mathrm{IL-1} \alpha$ (Fig. 3B). When the cells were cultured with $20 \mathrm{pg} / \mathrm{ml}$ rat IL- $1 \alpha$ for various periods of time, a time-dependent effect of IL-1 $\alpha$ on StAR expression was demonstrated. A significant stimulatory effect was evident within $3 \mathrm{~h}$ of incubation, reaching $8 \cdot 5$-fold increase over

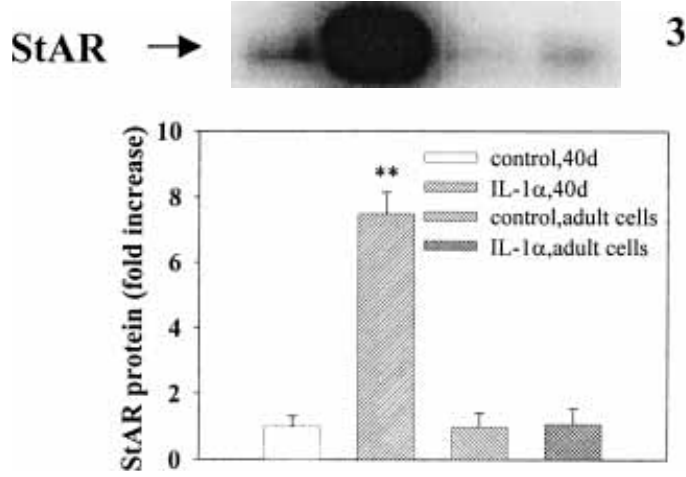

Figure 2 Effect of IL- $1 \alpha$ on StAR protein expression in immature and adult rat Leydig cells. Cells were cultured for $24 \mathrm{~h}$, fresh medium was added and the cultures were continued in the presence or absence of rat IL-1 $\alpha$ $(20 \mathrm{pg} / \mathrm{ml})$ for an additional $24 \mathrm{~h}$. Whole cell extracts ( $30 \mu \mathrm{g}$ protein) from both immature (40 day) and adult Leydig cells were analyzed by Western blotting using antiserum specific for StAR. Each StAR-specific band was quantified using $\mathrm{NIH}$ Image software and expressed as the fold difference vs cultured untreated control cells. The position of the StAR protein is indicated. Top, representative blot. Bottom, data from three separate Leydig cell preparations are presented (means \pm S.E.). ${ }^{* *} P<0.01$ compared with control from immature cells.

control $(P<0 \cdot 01)$ after $24 \mathrm{~h}$ (Fig. 4A). This effect was accompanied by an increase in androgen production by immature Leydig cells. The testosterone level was increased by $3 \mathrm{~h}$, and was maximally elevated at $24 \mathrm{~h}$ (Fig. 4B).

\section{IL-1 $\alpha$ induces phosphorylation of p38 MAP kinase in immature Leydig cells}

Since IL-1 signaling in many cell systems occurs through activation of p38 MAP kinase, we investigated whether IL- $1 \alpha$ activates p38 MAP kinase in immature Leydig cells in culture. IL- $1 \alpha$ elicited phosphorylation of p38 MAP kinase in immature cells, and the specific inhibitor of the kinase, SB203580, markedly suppressed this effect of IL-1 $\alpha$ (Fig. 5).

\section{Inhibition of p38 MAP kinase decreases IL-1 $\alpha$-induced testosterone production by immature Leydig cells}

To assay whether the activation of p38 MAP kinase is involved in IL-1 $\alpha$-mediated Leydig cell steroidogenesis, the p38 MAP kinase-specific inhibitors SB203580 and PD169316 were employed. Both 
A
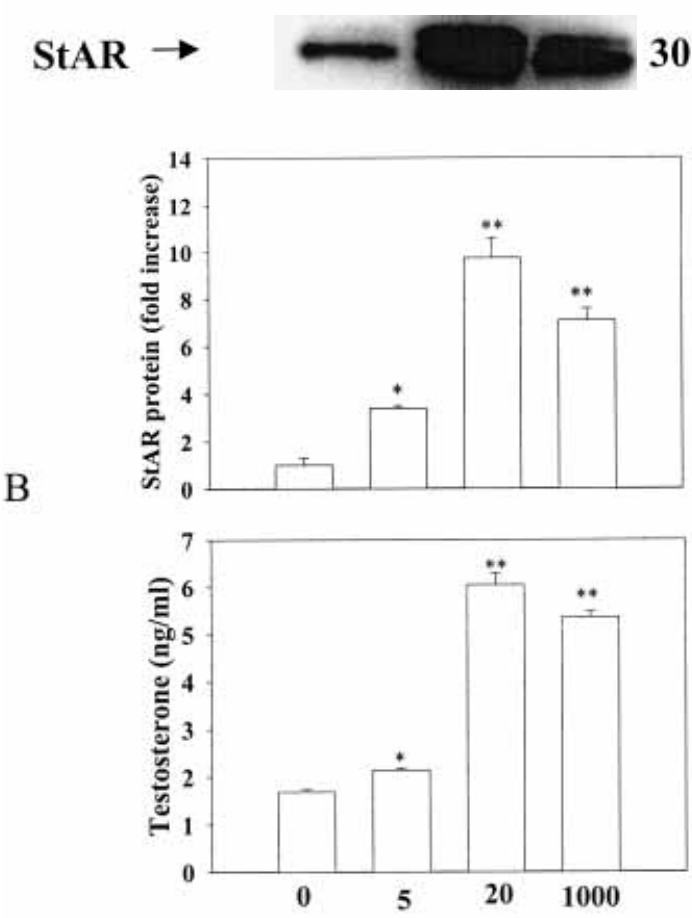

Concentration of IL-1 $\alpha(\mathrm{pg} / \mathrm{ml})$

Figure 3 Dose-dependent effect of IL- $1 \alpha$ on StAR protein expression and testosterone production by immature rat Leydig cells in vitro. Cells were cultured for $24 \mathrm{~h}$, fresh medium was added and the cells were incubated with or without increasing concentrations of rat IL-1 $\alpha$ for an additional $24 \mathrm{~h}$. (A) Whole cell lysates $(30 \mu \mathrm{g})$ were used to analyze StAR protein by Western blotting. Results are expressed as described in Fig. 2. The position of the StAR protein is indicated. Top, representative blot. Bottom, data from three separate Leydig cell preparations are presented (means \pm S.E.). (B) Testosterone production in the medium was measured by RIA. The results are means \pm S.E. of triplicate determinations. The results were confirmed in two additional experiments. ${ }^{\star} P<0.05,{ }^{* \star} P<0.01$ compared with control.

compounds significantly inhibited IL- $1 \alpha$-induced steroidogenesis in Leydig cells at the highest concentration $(0 \cdot 1 \mu \mathrm{M})$, resulting in about a $60 \%$ reduction of the IL- $1 \alpha$ effect (Fig. 6A). No effect on basal steroidogenesis was found (Fig. 6B).

To investigate the site of steroidogenesis affected by p38 MAP kinase inhibitors, the effect of SB203580 on androgen precursor-induced testosterone production by immature Leydig cells in culture was studied. Co-treatment of the cells with SB203580 and 22R-OHC completely reversed the
A

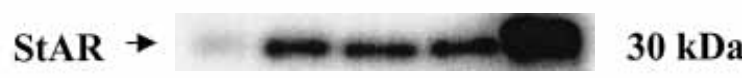

B
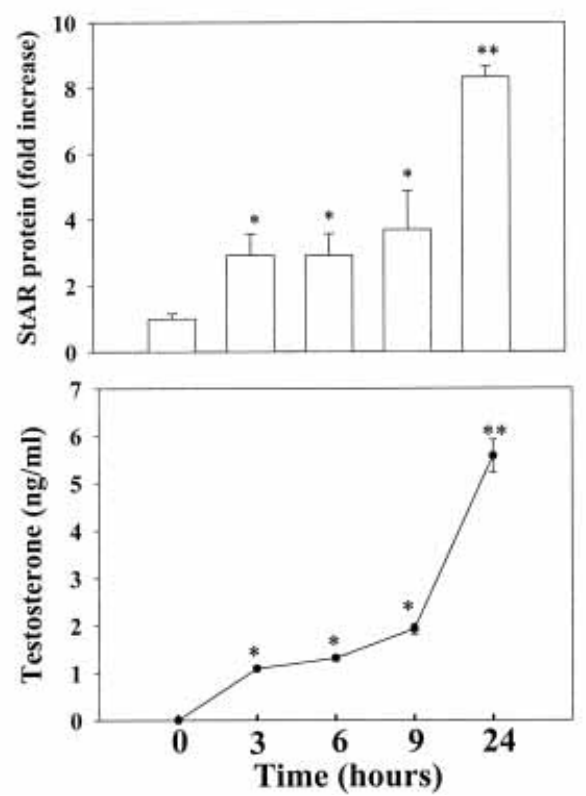

Figure 4 Time-dependent effect of IL- $1 \alpha$ on StAR protein expression and testosterone production by immature rat Leydig cells in vitro. Cells were cultured for $24 \mathrm{~h}$, fresh medium was added and the cultures were continued in the presence or absence of rat IL-1 $\alpha$ $(20 \mathrm{pg} / \mathrm{ml})$ for various periods of time. (A) Whole cell lysates $(30 \mu \mathrm{g})$ were used to analyze StAR protein by Western blotting. Results are expressed as described in Fig. 2. The position of the StAR protein is indicated. Top, representative blot. Bottom, data from three separate Leydig cell preparations are presented (means \pm S.E.). (B) testosterone production in the medium was measured by RIA. The results were confirmed in two additional experiments. ${ }^{*} P<0.05,{ }^{* *} P<0.01$ compared with control.

inhibition of steroidogenesis induced by the inhibitor (Fig. 7), suggesting that the expression of StAR protein might be regulated by p38 MAP kinase.

\section{Effect of p38 MAP kinase inhibitor SB203580 on IL-1 $\alpha$-induced StAR expression by immature Leydig cells}

Since the p38 MAP kinase inhibitors used inhibited androgen production stimulated by IL-1 $\alpha$, we investigated whether SB203580 may affect IL- $1 \alpha-$ induced StAR expression by Leydig cells. IL-1 $\alpha$ 


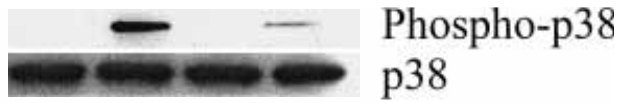

$\begin{array}{lllll}\text { Lane } & 1 & 2 & 3 & 4 \\ \text { IL-1 } \alpha & - & + & - & + \\ \text { SB203580 } & - & - & + & +\end{array}$

Figure 5 SB203580 inhibits IL- $1 \alpha$-induced phosphorylation of p38 MAP kinase in immature Leydig cells in vitro. The cultured cells were pretreated with $1 \mu \mathrm{M}$ SB203580 (lane 3 and 4) or vehicle for $30 \mathrm{~min}$, and then stimulated by rat IL-1 $\alpha(1 \mathrm{ng} / \mathrm{ml})$ (lane 2 and 4 ) or vehicle (lane 1 and 3 ) for $15 \mathrm{~min}$. The cells were lysed and $30 \mu \mathrm{g}$ total protein were used to analyze phosphorylated and total p38 MAP kinases by Western blotting. Upper panel, antibodies specific for phosphorylated p38 MAP kinase. Lower panel, anti-p38 MAP kinase antibodies. The results were confirmed in two additional experiments.

significantly (7-fold over control, $P<0 \cdot 01)$ stimulated StAR protein expression, while SB203580 markedly $(50 \%$ of the value with IL- $1 \alpha$ alone) suppressed this stimulation (Fig. 8). In a separate experiment the effect of SB203580 $(1 \mu \mathrm{M})$ on P450 scc expression was investigated. No significant changes in the P450 scc level after treatment with SB203580 $(1 \mu \mathrm{M})$ were found $(1 \cdot 000 \pm 0 \cdot 030$-fold in IL- $1 \alpha$-treated cells vs $1 \cdot 180 \pm 0 \cdot 035$-fold in IL- $1 \alpha+$ SB203580-treated cells, $P=0 \cdot 34$ ).

\section{Discussion}

The present study is the first to demonstrate that IL- $1 \alpha$ is a potent stimulator of StAR protein expression in immature but not adult Leydig cells. We provide evidence that this process is positively regulated by p38 MAP kinase. A stimulatory effect of IL-1 on basal testosterone production by rat Leydig cells in culture has previously been found in both prepubertal (Verhoeven et al. 1988) and adult animals (Moore \& Moger 1991) but the regulatory mechanisms of the process have been unclear. The present data have confirmed our previous suggestion that acute steroidogenesis induced by IL- $1 \alpha$ in immature Leydig cells is mediated by StAR protein (Svechnikov et al. 2001). In our experiments a close correlation between StAR protein expression activated by IL- $1 \alpha$ and testosterone production by Leydig cells was found. In contrast, no correlation between StAR protein expression and corticosterone production after acute short-term stimulation

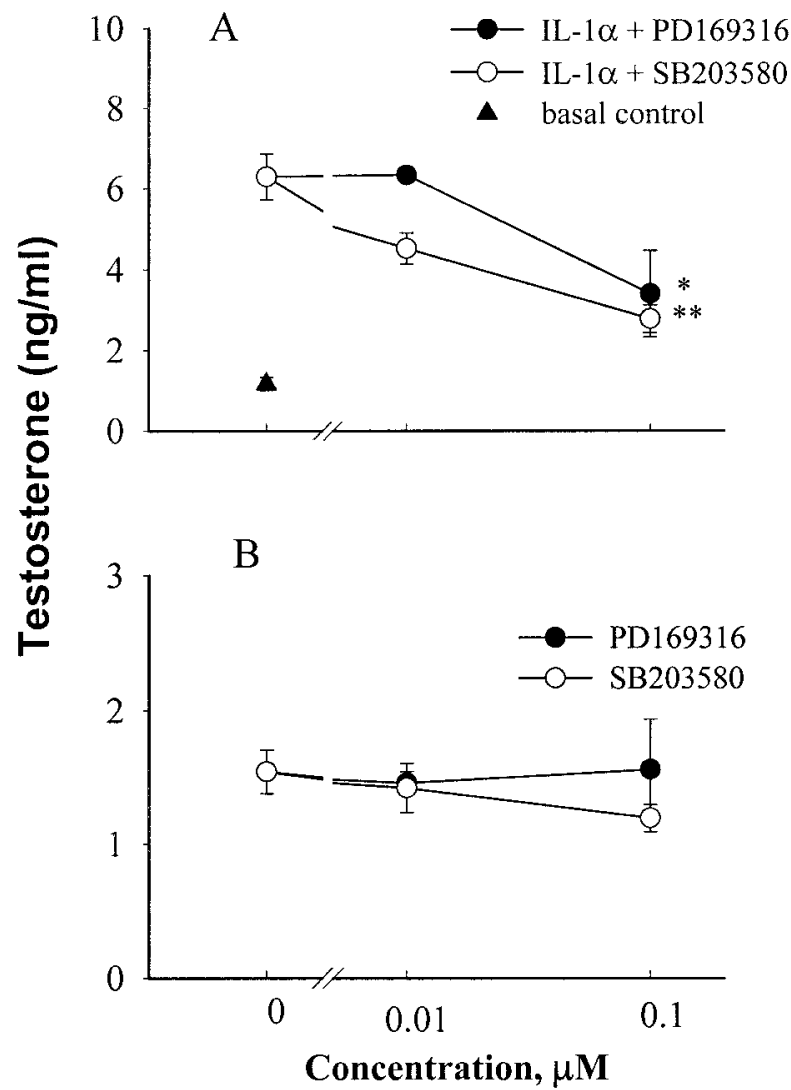

Figure 6 Inhibition of p38 MAP kinase abolishes $\mathrm{IL}-1 \alpha$-driven steroidogenesis in Leydig cells. Cells were cultured for $24 \mathrm{~h}$, fresh medium was added and the cells were pretreated with or without increasing concentrations of PD169316 or SB203580 for 30 min, and then incubated with rat IL-1 $\alpha(20 \mathrm{pg} / \mathrm{ml})(\mathrm{A})$ or vehicle (B) for an additional $24 \mathrm{~h}$. Testosterone production in the medium was measured by RIA. Results are means \pm S.E. of triplicate determinations. Each experiment was performed four times with the same results. ${ }^{*} P<0.05,{ }^{* *} P<0.01$ compared with the value of IL-1 $\alpha$ alone.

of adrenal cells with adrenocorticotropin (ACTH) has been shown, since only a small fraction of newly synthesized StAR was active (Artemenko et al. 2001). Differences in cell systems used (adrenocortical vs Leydig cells), time of treatment (short-term vs long-term stimulation) and types of activators used (ACTH vs IL-1 $\alpha$ ) might explain this discrepancy.

We show here that IL- $1 \alpha$ stimulates phosphorylation of p38 MAP kinase, suggesting that this enzyme is activated in the responding Leydig cell. The involvement of p38 MAP kinase in the regulation of StAR protein expression is supported 


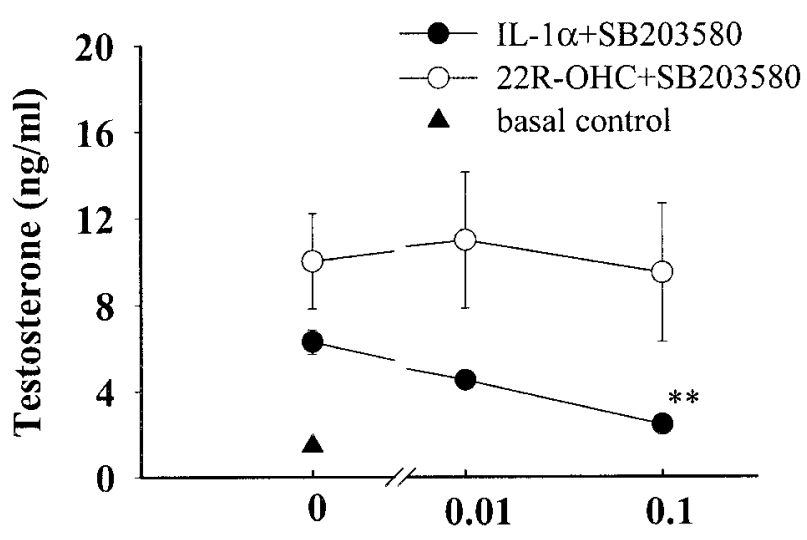

Concentration of SB203580 $(\mu \mathrm{M})$

Figure 7 Site of action of SB203580 on IL- $1 \alpha$ stimulated testosterone production by immature Leydig cells in vitro. Cells were cultured for $24 \mathrm{~h}$, fresh medium was added and the cells were pretreated with or without increasing concentrations of SB203580 for $30 \mathrm{~min}$, and then incubated with rat IL-1 $\alpha(20 \mathrm{pg} / \mathrm{ml})$ and $22 \mathrm{R}-\mathrm{OHC}$ $(1 \mu \mathrm{M})$ or vehicle for an additional $24 \mathrm{~h}$. Testosterone production in the medium was measured by RIA. Each experiment was performed four times with the same results. ${ }^{* *} P<0.01$ compared with the effect of IL-1 $\alpha$ alone.

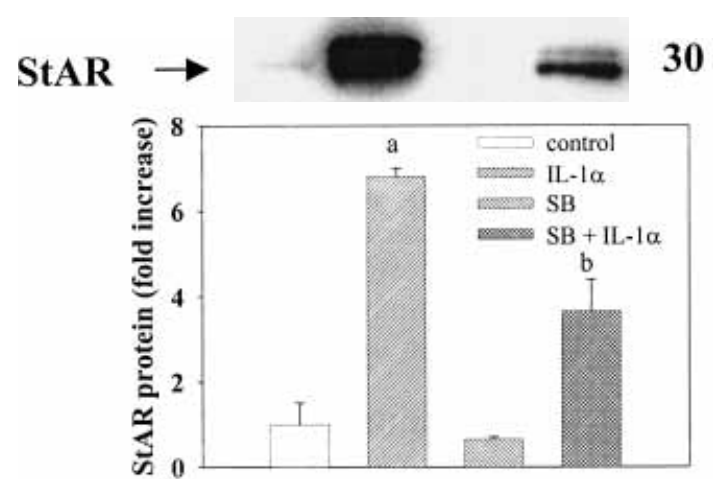

Figure 8 Inhibition of p38 MAP kinase decreases StAR expression induced by IL- $1 \alpha$ in immature Leydig cells in vitro. Cells were cultured for $24 \mathrm{~h}$, fresh medium was added and the cells were pretreated with SB203580 $(1 \mu \mathrm{M})$ or vehicle for $30 \mathrm{~min}$, and then incubated with rat IL-1 $\alpha(20 \mathrm{pg} / \mathrm{ml})$ or vehicle for an additional $24 \mathrm{~h}$. Whole cell extracts $(30 \mu \mathrm{g})$ were analyzed by Western blotting using antiserum specific for StAR. Results are expressed as described in Fig. 2. The position of the StAR protein is indicated. Top, representative blot. Bottom, data from four separate Leydig cell preparations are presented (means \pm S.E.). ${ }^{a} P<0.01$ compared with control, ${ }^{\mathrm{b}} P<0.05$ compared with the value of IL-1 $\alpha$ alone. by several observations. First, IL- $1 \alpha$-stimulated testosterone production was shown to be inhibited by both SB203580 and PD169316, specific inhibitors of p38 MAP kinase (Pearson et al. 2001), and this effect was abolished by 22R-OHC, a cell-permeable form of cholesterol. These findings give evidence that both inhibitors suppress Leydig cell steroidogenesis at the level of StAR protein, and that p38 MAP kinase seems to be involved in this process. Indeed, in further experiments SB203580 was found to significantly inhibit IL-1 $\alpha$-induced StAR expression. Moreover, we used low concentrations of p38 MAP kinase inhibitors (up to $1 \mu \mathrm{M}$ ), which were shown to specifically suppress activity of p38 MAP kinase without affecting activities of other kinases (Davies et al. 2000), adding to the relevance of our findings. One possible mechanism by which p38 MAP kinase activated by IL- $1 \alpha$ could promote StAR expression in Leydig cells is activation of the nuclear transcription factor G/EBP 3 (NF-IL6 or LAP). This factor belongs to the family of CCAAT/enhancer-binding proteins and has been reported to be an IL-1-inducible factor (Isshiki et al. 1990). The expression of $\mathrm{C} / \mathrm{EBP} \beta$ is activated by several inflammatory agents, such as IL-6, lipopolysaccharide and tumor necrosis factor- $\alpha$ (Metz \& Ziff 1991), and is one of the targets of p38 MAP kinase (Baldassare et al. 1999). Interestingly, $\mathrm{C} / \mathrm{EBP} \beta$ is expressed in steroidogenic cells, including Leydig cells (Nalbant et al. 1998) and ovarian granulosa cells (Sirois \& Richards 1993) and two putative C/EBP-binding sites in the StAR promoter have been identified (Reinhart et al. 1999, Silverman et al. 1999). Another transcriptional factor that is known to be one of the targets for p38 MAP kinase and was shown recently to be involved in StAR expression is a cAMP response-element binding protein (CREB). Transient expression of wild-type CREB in MA-10 mouse Leydig tumor cells was found to increase the levels of $(\mathrm{Bu})_{2} \mathrm{cAMP}$ induced StAR promoter activity, StAR mRNA and StAR protein expression. These responses were significantly inhibited by transfection with a dominant-negative CREB, or with a CREB mutant that cannot be phosphorylated (Manna et al. 2002). It can be hypothesized that p38 MAP kinase might regulates CREB phosphorylation and StAR gene expression through activation of the ribosomal S6 kinase (RSK) family member, RSK-B. This kinase is a p38 MAP kinase substrate and 
phosphorylates CREB and c-Fos proteins (Pierrat et al. 1998).

Activation of StAR expression by IL- $1 \alpha$ in immature Leydig cells can itself promote Leydig cell maturation. Immature Leydig cells expressing a higher level of StAR protein seem to have a significant capacity for producing androgens, which may be an important transition phase involved in the onset of adult Leydig cell differentiation. This hypothesis is consistent with the notion that androgens are required for the maturational acquisition of steroidogenic enzymes in later steps of Leydig cell postnatal maturation (MendisHandagama \& Ariyaratne 2001). Immature Leydig cells have been found to express the highest levels of both androgen receptor mRNA and protein (Buzek \& Sanborn 1988), suggesting that androgens are needed in the differentiation of these cells into adult Leydig cells. This suggestion is in agreement with the observation that administration of androgens restored Leydig cell morphology and function in LH-releasing hormone antagonisttreated immature rats (Misro et al. 1993).

Our findings demonstrating that IL-1RI expression is dependent on the maturational stage of Leydig cell development suggest that the amount of IL-1RI expressed might explain, at least in part, the different capacity of immature and adult Leydig cells to express StAR in response to IL- $1 \alpha$. The present data with IL-1RI protein confirm our previous finding of a stronger expression of IL-1RI mRNA in immature than in adult Leydig cells as revealed by RT-PCR analysis (Svechnikov et al. 2001). Moreover, we have previously shown that IL-1 receptor type II (IL-1RII) mRNA expression is detectable only in adult Leydig cells (Svechnikov et al. 2001). Since IL-1RII is a scavenger receptor neutralizing IL-1 action (Neumann et al. 2000), this may also contribute to the low response of adult cells to IL-1 action.

Collectively, our previous (Svechnikov et al. 2001) and present data form the basis of a hypothesis that IL- $1 \alpha$ is an important paracrine factor involved in the onset of final Leydig cell maturation. This suggestion is supported by several observations. First, we have recently shown that IL- $1 \alpha$ has biological action on Leydig cell function by activating steroidogenesis in immature Leydig cells (Svechnikov et al. 2001). This effect was receptormediated and blockade of IL-1RI reversed IL- $1 \alpha$-mediated effects. Secondly, IL- $1 \alpha$ is detect- able in the rat testis from postnatal day 20 and reaches high concentrations from day 25 (Jonsson et al. 1999, Wahab-Wahlgren et al. 2000). Moreover, the intratesticular concentration of IL- $1 \alpha$ protein in the rat testis is in the same bioactive range as those used in our present Leydig cell cultures in vitro (Gustafsson et al. 1988, 2002, Wahab-Wahlgren et al. 2000, Jonsson et al. 2001), adding to the potential physiological relevance of our findings.

In conclusion, the results of the current study show clearly and for the first time that IL- $1 \alpha$ is a potent stimulator of StAR protein expression in immature but not adult Leydig cells. IL- $1 \alpha$-induced StAR expression is positively regulated by p38 MAP kinase in immature Leydig cells. The data presented here suggest that IL- $1 \alpha$ is an important paracrine factor regulating postnatal Leydig cell maturation and IL- $1 \alpha$-mediated StAR protein expression is one of the mechanisms that might contribute to differentiation of immature Leydig cells into adult cells.

\section{Acknowledgements}

This study was supported by grants from the Foundation for Strategic Environmental Research (MISTRA), the Swedish Research Council (Project No. 8282), Frimurare Barnhuset in Stockholm, HRH Crown Princess Lovisa Society of Pediatric Health Care, the Children Cancer Fund, the Cancer Foundation, the Society for Child Care, the Åke Wiberg Foundation, NIH Grant HD17481 and funds from the Robert A Welch Foundation. The results were partly presented as an abstract at the 12th European Testis Workshop in Doorwerth, The Netherlands, April 2002.

\section{References}

Artemenko IP, Zhao D, Hales DB, Hales KH \& Jefcoate CR 2001 Mitochondrial processing of newly synthesized steroidogenic acute regulatory protein (StAR), but not total StAR, mediates cholesterol transfer to cytochrome P450 side chain cleavage enzyme in adrenal cells. Fournal of Biological Chemistry $\mathbf{2 7 6}$ 46583-46596.

Baldassare JJ, Bi Y \& Bellone CJ 1999 The role of p38 mitogen-activated protein kinase in IL-1 beta transcription. Fournal of Immunology 162 5367-5377.

Bankers-Fulbright JL, Kalli KR \& McKean DJ 1996 Interleukin-1 signal transduction. Life Sciences 59 61-83. 
Buzek SW \& Sanborn BM 1988 Increase in testicular androgen receptor during sexual maturation in the rat. Biology of Reproduction 39 39-49.

Calkins JH, Sigel MM, Nankin HR \& Lin T 1988 Interleukin-1 inhibits Leydig cell steroidogenesis in primary culture. Endocrinology $1231605-1610$.

Christenson LK \& Strauss JF III 2000 Steroidogenic acute regulatory protein (StAR) and the intramitochondrial translocation of cholesterol. Biochimica et Biophysica Acta 1529 175-187.

Clark BJ, Wells J, King SR \& Stocco DM 1994 The purification, cloning, and expression of a novel luteinizing hormone-induced mitochondrial protein in MA-10 mouse tumor Leydig cells. Characterization of the steroidogenic acute regulating protein (StAR). Fournal of Biological Chemistry $26928314-28322$.

Davies SP, Reddy H, Caivano M \& Cohen P 2000 Specificity and mechanism of action of some commonly used protein kinase inhibitors. Biochemical fournal 351 95-105.

Dinarello CA 1991 Interleukin-1 and interleukin-1 antagonism. Blood 77 1627-1652.

Ge R-S, Shan L-X \& Hardy MP 1996 Pubertal development of Leydig cells. In The Leydig Cell, pp 159-174. Eds AH Payne, MP Hardy \& LD Russell. Vienna: Cache River Press.

Gustafsson K, Söder O, Pöllänen P \& Ritzén EM 1988 Isolation and partial characterization of an interleukin-1-like factor from rat testis interstitial fluid. Fournal of Reproductive Immunology 14 139-150.

Gustafsson K, Sultana T, Zetterström CK, Setchel BP, Siddiqui A, Günther W \& Söder O 2002 Production and secretion of interleukin- $1 \alpha$ proteins by rat testis. Biochemical and Biophysical Research Communications 297 492-497.

Gyles SL, Burns CJ, Whitehouse BJ, Sugden D, Marsh PJ, Persaud SJ \& Jones PM 2001 ERKs regulate cyclic AMP-induced steroid synthesis through transcription of the steroidogenic acute regulatory (StAR) gene. Fournal of Biological Chemistry 276 34888-34895.

Isshiki H, Akira S, Tanabe O, Nakajama T, Shimamoto T, Hirano T \& Kishimato T 1990 Constitutive and interleukin-1 (IL-1)-inducible factors interact with the IL-1-responsive element in the IL-6 gene. Molecular and Cellular Biology 10 2757-2764.

Jonsson CK, Zetterström RH, Holst M, Parvinen M \& Söder O 1999 Constitutive expression of interleukin- $1 \alpha$ messenger ribonucleic acid in rat Sertoli cells is dependent upon interaction with germ cells. Endocrinology $1403755-3761$.

Jonsson C, Setchell B, Martinelle N, Svechnikov K \& Söder O 2001 Endotoxin-induced interleukin-1 expression in testicular macrophages is accompanied by down-regulation of the constitutive expression in Sertoli cells. Cytokine 14 283-288.

Khan SA, Söder O, Syed V, Gustafsson K, Lindh M \& Ritzén M 1987 The rat testis produces large amounts of an interleukin-1-like factor. International fournal of Andrology 10 495-503.

Manna PR, Dyson MT, Eubank DW, Clark BJ, Lalli E, Sassone-Corsi P, Zeleznik AJ \& Stocco DM 2002 Regulation of steroidogenesis and the steroidogenic acute regulatory protein by a member of the cAMP response-element binding protein family. Molecular Endocrinology 16 184-199.

Mendis-Handagama SM \& Ariyaratne HB 2001 Differentiation of the adult Leydig cell population in the postnatal testis. Biology of Reproduction 65 660-671.

Metz R \& Ziff E 1991 cAMP stimulates the C/EBP-related transcription factor rNF IL-6 to translocate to the nucleus and induce c-fos transcription. Genes and Development 5 1754-1766.

Misro MM, Ganguly A \& Das RP 1993 Is testosterone essential for maintenance of normal morphology in immature rat Leydig cells? International Fournal of Andrology 16 221-226.

Moore C \& Moger WH 1991 Interleukin- $1 \alpha$-induced changes in androgen and cyclic adenosine $3^{\prime}, 5^{\prime}$-monophosphate release in adult rat Leydig cells in culture. Fournal of Endocrinology 129 381-390.
Nalbant D, Williams SC, Stocco DM \& Khan S 1998 Luteinizing hormone-dependent gene regulation in Leydig cells may be mediated by CCAAT/enhancer binding protein-beta. Endocrinology $139272-279$

Neumann D, Kollewe G, Martin MU \& Boraschi D 2000 The membrane form of the type II IL-1 receptor account for inhibitory function. Fournal of Immunology 165 3350-3357.

Parvinen M, Söder O, Mali P, Fröysa B \& Ritzen EM 1991 In vitro stimulation of stage-specific deoxyribonucleic acid synthesis in rat seminiferous tubule segments by interleukin-l $\alpha$. Endocrinology 129 $1614-1620$.

Payne AH, Downing JR \& Wong KL 1980 Luteinizing hormone receptors and testosterone synthesis in two distinct populations of Leydig cells. Endocrinology 106 1424-1429.

Pearson G, Robinson F, Gibson TB, Xu B-E, Karandikar M, Berman K \& Cobb MH 2001 Mitogen-activated protein (MAP) kinase pathways: regulation and physiological functions. Endocrine Reviews 22 153-183.

Pierrat B, Correia JS, Mary J-L \& Tomás-Zuber M 1998 RSK-B, a novel ribosomal S6 kinase family member, is a CREB kinase under dominant control of p38 $\alpha$ mitogen-activated protein kinase $\left(\mathrm{p} 38 \alpha^{\mathrm{MAPK}}\right)$. Fournal of Biological Chemistry 273 29661-29671.

Pöllänen P, Söder O \& Parvinen M 1989 Interleukin-1 $\alpha$ stimulation of spermatogonial proliferation in vivo. Reproduction, Fertility, and Development 1 85-87.

Reinhart AJ, Williams SC, Clark BJ \& Stocco DM 1999 SF-1 (steroidogenic factor-1) and C/EBP beta (CCAAT/enhancer binding protein-beta) cooperate to regulate the murine StAR (steroidogenic acute regulatory) promoter. Molecular Endocrinology $13729-741$

Silverman E, Eimerl S \& Orly J 1999 CCAAT enhancer-binding protein beta and GATA-4 binding regions within the promoter of the steroidogenic acute regulatory protein $(\mathrm{StAR})$ gene are required for transcription in rat ovarian cells. Fournal of Biological Chemistry 274 17987-17996.

Sirois J \& Richards JS 1993 Transcriptional regulation of the rat prostaglandin endoperoxidase syntase 2 gene in granulosa cells. Evidence for the role of a cis-acting C/EBP beta promoter element. Fournal of Biological Chemistry 268 21931-21938.

Stocco DM 2001 StAR protein and the regulation of steroid hormone biosynthesis. Annual Review of Physiology 63 193-213.

Sultana T, Svechnikov K, Weber G \& Söder O 2000 Molecular cloning and expression of a functionally different alternative splice variant of prointerleukin- $1 \alpha$ from the rat testis. Endocrinology 141 4413-4418.

Svechnikov KV, Sultana T \& Söder O 2001 Age-dependent stimulation of Leydig cell steroidogenesis by interleukin-1 isoforms. Molecular and Cellular Endocrinology 182 193-201.

Tovey MG, Content J, Gresser I, Gugenheim J, Blanchard B, Guymarho J, Poupart P, Gigou M, Shaw A \& Fiers W 1988 Genes for IFN- $\beta-2$ (IL-6), tumor necrosis factor, and IL-1 are expressed at high levels in the organs of normal individuals. Fournal of Immunology 141 3106-3110.

Verhoeven G, Cailleau J, Van Damme J \& Billiau A 1988 Interleukin-1 stimulates steroidogenesis in cultured rat Leydig cells. Molecular and Cellular Endocrinology 57 51-60.

Wahab-Wahlgren A, Holst M, Ayele D, Sultana T, Parvinen M, Gustafsson K, Granholm T \& Söder O 2000 Constitutive production of interleukin- $1 \alpha$ mRNA and protein in the developing rat testis. International Fournal of Andrology 23 360-365.

Wang XJ, Walsh LP, Reinhart AJ \& Stocco DM 2000 The role of arachidonic acid in steroidogenesis and steroidogenic acute regulatory (StAR) gene and protein expression. Fournal of Biological Chemistry $27520204-20209$.

Received in final form 28 October 2002 Accepted 8 November 2002 